Bangladesh J. Bot. 49(4): 1119-1125, 2020 (December)

\title{
ANTIMICROBIAL EFFECTS OF VERBASCUM THAPSUS L. LEAF EXTRACTS
}

\author{
WaJid Khan*, Rizwan Ullah, Zainul WaHaB \\ aNd Muhammad Nazir UdDin \\ Center for Biotechnology and Microbiology, University of Swat, \\ Saidu Road, Mingora, Pakistan
}

Keywords: Verbascum thapsus, Antimicrobial activity, Leaf extracts

\begin{abstract}
Antimicrobial activity of leaves of Verbascum thapsus L. using different extractions solvents was evaluated. Extracts were prepared and tested against different bacterial (Pseudomonas aeruginosa, Klebsiella pneumoniae, Bacillus atrophaeus, Salmonella typhi, Citrobacter freundii and fungal species (Alternaria solani, Candida albicans, Aspergillus fumigatus). Disc and well diffusion assays were used for screening antibacterial and antifungal potential of extracts. The ethyl acetate extract produced the maximum zone of inhibition (70\% ZI) against K. pneumoniae at $3000 \mu \mathrm{g} /$ disc. Methanol extracts formed $68 \% \mathrm{ZI}$ against $S$. typhi, 54\% ZI against $A$. tumefacian and 50\% ZI against $C$. freundii, respectively at $3000 \mu \mathrm{g} / \mathrm{disc}$ respectively. Against the fungal species, the methanol extract was effective and formed maximum zone of inhibition (50\% ZI) against $A$. solani at $3000 \mu \mathrm{g} /$ well. Hexane extract was moderately active against bacterial species but inactive against tested fungal species. T. rubrum was resistant and none of the tested extracts affected its growth.
\end{abstract}

\section{Introduction}

Bioactive compounds of the plants are used for drug development and synthesis (Hassan et al. 2012). Allopathic and other antibiotic drugs are costly and have side effects on human health so people use medicinal plants as the first choice for health care (Riaz et al. 2013). According to a report of WHO most people of less developed countries and more than 3 billion people of developed countries use medicinal plants for the treatment of different diseases (Ahvazi et al. 2012). Verbascum thapsus is one of the medicinal plants belonging to a family Scrophulariaceae and the most important species of genus Verbascum (Cabi et al. 2011). V. thapsus is mainly found in forest, rocky land and on the roadside (Guerel and Turker 2005). It is found all over the world and is known by their local names like Khardag, Candlewick plant, Velvet plant, Gidder tambakoo and common mullein (Qureshi et al. 2007, Sher 2011). It is used as folk medicine against different diseases from the very past (Camper and Turker 2002). Aerial portion of V. thapsus was used for the treatment of urinary diseases, wounds and edema (Rajbhandari et al. 2009). Chest and abdominal problems can be reduced by the extracts of V. thapsus (Murad et al. 2011). Dried roots, leaves, flower capsule extracts are commonly available in the market of US (Riaz et al. 2013).

Extracts of the $V$. thapsus has reported for antifungal, antioxidant, antibacterial and antiadherent activities (Ghasemi et al. 2015, Kalalian-Moghaddam et al. 2015). Despite of this research studies to unveil the pharmacological importance of $V$. thapsus, the true gigantic antibacterial potency of this plant still remains hidden. The antibacterial and other biological activity of the extract depend on the extraction solvent and mode of extraction (Khan et al. 2016, Onivogui et al. 2016). The increasing polarity order of the solvents based extraction from the leaves of $V$. thapsus was used for the first time in the present study. This research work provides the answer for the queries like, what confers the difference in the effectiveness of different extract produce from the same part of this plant? and what type of extracts should be further processed for

*Author for correspondence: <sherafghan.shah@gmail.com>. 
the isolation of bioactive compounds and drug development. Therefore, the aim of the present was to evaluate the effect of extraction solvents on the antimicrobial and antioxidant potential of the leaf extracts of $V$. thapsus.

\section{Materials and Methods}

The plants were found in different localities of district Malakand. Plant material was collected from Totakan area of district Malakand during January, 2017. After collection, the leaves were dried at room temperature under shady place and then converted to powder form with the help of a grinding machine.

Nutrient agar, nutrient broth and Di methyl Sulfo Oxide (DMSO) were purchased from a local supplier, Musaji Adam \& Sons. Methanol, ethyl acetate, N-hexane and water were used as solvent for extraction. The rotary evaporator was used for extraction from the plant material.

Two hundred and twenty-six gram of leaves in powder form was taken in conical flasks. Two thousand $\mathrm{ml}$ methanol was added to a flask containing leaf material. The flask was shaken regularly for six consecutive days. The solution was separated from insoluble material by filtration. Fresh methanol was added to residues for more filtrate production. The filtrate was then dried through rotary evaporator at $37^{\circ} \mathrm{C}$. After drying $105 \mathrm{~g}$ of leaves extract was obtained. Out of $105 \mathrm{~g}$ of leaves extract, $5 \mathrm{~g}$ was used for antimicrobial activity while $100 \mathrm{~g}$ was dissolved in distilled water. The extract dissolved in water was taken in a separatory funnel. N-hexane (300 $\mathrm{ml})$ was poured into the separatory funnel and shaken gently for 2-3 min. After shaking, the upper layer (hexane part) was poured into the label and clean bottle while the remaining part was reextracted three times with fresh hexane. Ethyl acetate $(300 \mathrm{ml})$ was then added to the separatory funnel containing water extract and shaken it. The upper layer of ethyl acetate was decanted and the same procedure was repeated three times. Finally hexane ethyl acetate were dried through rotary evaporator at $37^{\circ} \mathrm{C}$ (Khan et al. 2016).

Nutrient agar, potato dextrose agar and nutrient broth were prepared according to manufacturer protocol. Antibacterial activity of the extract was carried out by disk diffusion method and antifungal activity by well diffusion assay. The bacterial strains (E. coli, A. tumefaciens, $S$. aureus, K. pneumoniae, $P$ aeruginosa, $S$. typhi, B. autrophus, B. aeruginosa) and fungal species (A. solani, C. albicane, A. fumigatus, A. niger and T. rubrum) were used in this study. About $50 \mu \mathrm{l}$ of standardized bacterial culture was spread on a nutrient agar plate and placed the disc on plates. Extracts of three different concentrations (1000, 2000 and $3000 \mu \mathrm{g} / \mathrm{disc})$ were applied to the discs and the plates were incubated in the incubator for $24 \mathrm{hrs}$. For testing the antifungal activity of the extracts, wells were formed in PDA plates and filled with extracts (1000, 2000 and $3000 \mu \mathrm{g}$ ). Fungus block of 5 days old culture was placed in the center of the plate. The same procedure was also applied for antibiotic (Ciprofloxacin) and antifungal solution (Clotrimazole) used as positive controls (Khan et al. 2017). DMSO was used as negative control in this study. The activity of the extract was measured in term of per cent zone of inhibition. The per cent zone of inhibition of extract was measured using the following formula after testing the extract three times.

(\%) antibacterial/antifungal activity $=$ (Zone of inhibition produced by sample/zone of inhibition produced by control) $\times 100$.

The statistical software Statistix 8.1 (Data analysis software) was used for the analysis of the data. The difference among the activity of the extracts was computed using analysis of variance (one-way ANOVA) following LSD test at significance level of 5\% ( $\mathrm{p} \leq 0.05)$. 


\section{Results and Discussion}

The bioactivities of the plant material depend on solvent extraction system and mode of extraction (Khan et al. 2018). Three different solvents (ethyl acetate, methanol and hexane) were used for the preparation of an extract from the leaves of $V$. thapsus. The extracts of $V$. thapsus from leaves showed antibacterial and antifungal (Tables 1, 2 and 3). Ethyl acetate extracts were higher than other tested extracts in their antibacterial potential $(\mathrm{p} \leq 0.05)$. Among all the tested extract from $V$. Thapsus leaves, ethyl acetate extract showed high potency against $P$. aeruginosa and this extract demonstrated 57\% ZI at $3000 \mu \mathrm{g} /$ disc followed by methanol extract (51\% ZI) and

Table 1. Anti-bacterial potential of the different extracts of the leaf of Verbascum thapsus against the different bacterial species

\begin{tabular}{|c|c|c|c|c|}
\hline \multirow{2}{*}{$\begin{array}{l}\text { Bacteria } \\
\text { species }\end{array}$} & \multirow{2}{*}{ Extracts } & \multicolumn{3}{|c|}{$\%$ zone of inhibition $\pm \mathrm{Sd} \quad(\mu \mathrm{g} /$ disc $)$} \\
\hline & & 1000 & 2000 & 3000 \\
\hline \multirow[t]{3}{*}{ P. aeruginosa } & Methanol & $33 \pm 1.5$ & $50 \pm 1.0$ & $51 \pm 0.95$ \\
\hline & n-hexane & $26 \pm 1.6$ & $35 \pm 1.3$ & $37 \pm 1.2$ \\
\hline & Ethyl acetate & $36 \pm 2.7$ & $50 \pm 2.1$ & $57 \pm 2.1$ \\
\hline \multirow[t]{3}{*}{ E. coli } & Methanol & $39 \pm 1.2$ & $44 \pm 1.3$ & $45 \pm 1.7$ \\
\hline & $n$-hexane & $33 \pm 1.1$ & $41 \pm 1.2$ & $42 \pm 1.4$ \\
\hline & Ethyl acetate & $24 \pm 1.0$ & $38 \pm 1.1$ & $40 \pm 1.1$ \\
\hline \multirow[t]{3}{*}{ S. typhi } & Methanol & $28 \pm 1.4$ & $36 \pm 1.3$ & $37 \pm 1.6$ \\
\hline & $n$-hexane & $39 \pm 1.6$ & $40 \pm 1.2$ & $42 \pm 1.5$ \\
\hline & Ethyl acetate & $45 \pm 1.7$ & $65 \pm 1.9$ & $70 \pm 2.1$ \\
\hline \multirow[t]{3}{*}{ A. tumefaciens } & Methanol & $50 \pm 1.1$ & $54 \pm 1.6$ & $56 \pm 1.1$ \\
\hline & $n$-hexane & $40 \pm 1.3$ & $43 \pm 1.1$ & $45 \pm 1.5$ \\
\hline & Ethyl acetate & $40 \pm 1.7$ & $40 \pm 1.1$ & $51 \pm 1.6$ \\
\hline \multirow[t]{3}{*}{ B. aeruginosa } & Methanol & $33 \pm 1.5$ & $36 \pm 1.4$ & $42 \pm 1.2$ \\
\hline & $n$-hexane & $40 \pm 1.3$ & $49 \pm 1.1$ & $52 \pm 1.5$ \\
\hline & Ethyl acetate & $36 \pm 0.9$ & $40 \pm 1.1$ & $45 \pm 1.2$ \\
\hline \multirow[t]{3}{*}{ S. aureus } & Methanol & $16 \pm 1.9$ & $25 \pm 1.6$ & $33 \pm 1.3$ \\
\hline & $n$-hexane & $13 \pm 1.7$ & $21 \pm 1.6$ & $39 \pm 1.3$ \\
\hline & Ethyl acetate & $36 \pm 1.2$ & $37 \pm 1.4$ & $51 \pm 1.3$ \\
\hline \multirow[t]{3}{*}{ C. freundii } & Methanol & $28 \pm 1.2$ & $35 \pm 1.1$ & $36 \pm 1.2$ \\
\hline & $n$-hexane & $25 \pm 1.2$ & $30 \pm 1.2$ & $35 \pm 1.6$ \\
\hline & Ethyl acetate & $22 \pm 0.9$ & $27 \pm 1.4$ & $33 \pm 0.9$ \\
\hline \multirow[t]{6}{*}{ B. atrophaeus } & Methanol & $40 \pm 1.6$ & $48 \pm 2.5$ & $50 \pm 1.3$ \\
\hline & $n$-hexane & $8 \pm 1.3$ & $25 \pm 1.6$ & $50 \pm 1.2$ \\
\hline & Ethyl acetate & $20 \pm 1.1$ & $37 \pm 2.1$ & $40 \pm 1.1$ \\
\hline & Methanol & $28 \pm 1.2$ & $36 \pm 1.1$ & $37 \pm 1.3$ \\
\hline & $n$-hexane & $39 \pm 1.4$ & $40 \pm 1.4$ & $42 \pm 15$ \\
\hline & Ethyl acetate & $45 \pm 1.7$ & $65 \pm 1.7$ & $70 \pm 1.9$ \\
\hline
\end{tabular}

Concentrations 1000, 2000 and $3000 \mu \mathrm{g}$ of the extract solution applied to the disc. 
hexane extracts $(37 \% \mathrm{ZI})$. On other hand ethyl acetate and methanol extracts produced the same zone of inhibition against $P$. aeruginosa at $2000 \mu \mathrm{g} / \mathrm{disc}(56 \% \mathrm{ZI})$ descended by hexane extract (40\% ZI). The extracts at $1000 \mu \mathrm{g} / \mathrm{disc}$ and showed $36 \% \mathrm{ZI}$ by ethyl acetate followed by methanol $(33 \% \mathrm{ZI})$ and hexane $(26 \% \mathrm{ZI})$ extract against the tested microbe. On testing the extracts against E. coli at $3000 \mu \mathrm{g} / \mathrm{disc}$, ethyl acetate extract (40\% ZI) was comparatively less active as compared to methanol and $(45 \% \mathrm{ZI})$ and hexane extract $(42 \% \mathrm{ZI})$. At $2000 \mu \mathrm{g} /$ disc methanol extract formed

Table 2. Anti-fungal potential of the different extracts of the leaf of Verbascum thapsus against the bacteria.

\begin{tabular}{llccc}
\hline \multirow{2}{*}{$\begin{array}{l}\text { Bacteria } \\
\text { species }\end{array}$} & Extracts & \multicolumn{3}{c}{$\%$ zone of inhibition $\pm \mathrm{Sd}(\mu \mathrm{g} / \mathrm{disc})$} \\
\cline { 3 - 5 } A. solani & Methanol & $39 \pm 1.5$ & $45 \pm 1.0$ & $50 \pm 000$ \\
& $n$-hexane & $0 \pm 0$ & $0 \pm 0$ & $0 \pm 0$ \\
& Ethyl acetate & $25 \pm 1.1$ & $27 \pm 1.3$ & $33 \pm 1.5$ \\
C. albicans & Methanol & $40 \pm 1.2$ & $43 \pm 1.6$ & $46 \pm 1.7$ \\
& $n$-hexane & $0 \pm 0$ & $0 \pm 0$ & $0 \pm 0$ \\
& Ethyl acetate & $35 \pm 1.0$ & $35 \pm 1.1$ & $37 \pm 1.2$ \\
A. fumigatus & Methanol & $39 \pm 1.5$ & $40 \pm 1.0$ & $42 \pm 0.9$ \\
& $n$-hexane & $0 \pm 0$ & $0 \pm 0$ & $0 \pm 0$ \\
& Ethyl acetate & $32 \pm 1.1$ & $33 \pm 1.6$ & $34 \pm 1.5$ \\
A. niger & Methanol & $24 \pm 1.3$ & $29 \pm 1.6$ & $34 \pm 1.2$ \\
& $n$-hexane & $0 \pm 0$ & $0 \pm 0$ & $39 \pm 1.5$ \\
& Ethyl acetate & $19 \pm 1.1$ & $21 \pm 1.2$ & $27 \pm 1.6$ \\
\hline
\end{tabular}

Table 3 . Overall antibacterial and anti-fungal potential of the extracts in different solvent extraction system.

\begin{tabular}{lcc}
\hline Extract & $\begin{array}{c}\text { Antibacterial activity of } \\
\text { extract }\end{array}$ & $\begin{array}{c}\text { Antifungal activity of the } \\
\text { extracts }\end{array}$ \\
\hline & $\begin{array}{c}\text { Per cent zone of } \\
\text { inhibition } \pm \mathrm{Sd}\end{array}$ & $\begin{array}{c}\text { Per cent zone of } \\
\text { inhibition } \pm \mathrm{Sd}\end{array}$ \\
Methanol & $39.6 \pm 9 \mathrm{~b}$ & $39.4 \pm 7 \mathrm{a}$ \\
Ethyl acetate & $43.6 \pm 13 \mathrm{a}$ & $30.1 \pm 5.7 \mathrm{~b}$ \\
Hexane & $36.4 \pm 10 \mathrm{ab}$ & $0 \pm 0 \mathrm{c}$ \\
\hline
\end{tabular}

The values in the same column represented by different letter (a-c) differ significantly at $\mathrm{p} \leq 0.05$ using LSD test.

inhibition zone of $44 \%$, followed by hexane (41\% ZI) and ethyl acetate extract (38\% ZI). However, observable differences in the potency of extracts were noted at a concentration of 1000 $\mu \mathrm{g} /$ disc against $E$. coli, in which ethyl acetate produced the least zone of inhibition (24\% ZI), elevated by hexane (33\% ZI) and methanol extract (39\% ZI). Prakash et al. (2016) reported that leaves extract of $V$. thapsus was active against $P$. aeruginosa, E. coli etc. Similarly, Ghasemi 
(2015) stated that methanol extract of $V$. Thapsus flower oil was effective against the bacterial strain of $E$. coli however Gram-positive bacteria were more susceptible to ethyl acetate extract in contrast to methanol extract of leaves. Ethyl acetate extract of $V$. thapsus against $K$. pneumoniae surpassed hexane (56\% ZI) and methanol extract (50\% ZI) by producing $75 \% \mathrm{ZI}$ at $3000 \mu \mathrm{g} / \mathrm{disc}$. Furthermore, the ethyl acetate extract was more effective than hexane $(37 \% \mathrm{ZI})$ and methanol extract (35\% ZI) by producing 75\% ZI at $2000 \mu \mathrm{g} / \mathrm{disc}$. The tested extracts were also active at $1000 \mu \mathrm{g} /$ disc against $K$. pneumoniae (ethyl acetate extract showed 53\% ZI, hexane and methanol produced $46 \%$ ZI and 33\% ZI). Findings of the research further stated that ethyl acetate extract was more active against $S$. aureus than methanol and hexane extracts. At $3000 \mu \mathrm{g} / \mathrm{disc}$, ethyl acetate extract produced $51 \%$ zone of inhibition against tested bacterium while hexane and methanol extract revealed 39 and 33\% ZI, respectively. Similarly, ethyl acetate extract, methanol and hexane extract at $2000 \mu \mathrm{g} /$ disc reduced the growth of $S$. aureus by 37, 25 and $21 \%$ (ZI), respectively as compared to control. The tested extracts were also active at $1000 \mu \mathrm{g} / \mathrm{disc}$ (36\% by ethyl acetate, $16 \% \mathrm{ZI}$ and $13 \%$ by methanol extract). The methanol extract of leaves of $V$. thapsus was potent against $S$. aureus, E. coli, B. aeruginosa, K. pneumoniae was reported by Khan et al. (2011). The results indicated that against $S$. aureus the extracts of $V$. thapsus leaves, methanol, ethyl acetate, and hexane were less active. Prakash et al. (2016) stated that acetone extract of $V$. thapsus leaves was more active against $S$. aureus. This difference in antimicrobial action might be due to the result of different solvent use, acetone solvent might extract a high concentration of bioactive compounds that affected the growth of S. aureus (Ngo et al. 2017).The finding of the present study also revealed that methanol extract of leaves was more effective against $S$. typhi, A. tumefacian and $C$. freundii as compared to other extracts. Methanol extracts formed 68\% ZI against $S$. typhi, 54\% ZI against $A$. tumefacian and 50\% ZI against $C$. freundii at $3000 \mu \mathrm{g} / \mathrm{disc}$. At $2000 \mu \mathrm{g} / \mathrm{disc}$ and $1000 \mu \mathrm{g} / \mathrm{disc}$, methanol extracts were still more active than other extracts. Against $B$. atrophus methanol and hexane extracts (50\% ZI) was more effective than ethyl acetate extract $(40 \% \mathrm{ZI})$ at $3000 \mu \mathrm{g} / \mathrm{disc}$. Same zone of inhibition was formed at $2000 \mu \mathrm{g} / \mathrm{disc}$ by ethyl acetate and methanol extracts (37\% ZI) followed by hexane extract $(25 \% \mathrm{ZI})$. The tested extracts were also active at $1000 \mu \mathrm{g} / \mathrm{disc}(8,20$ and $30 \% \mathrm{ZI}$ by hexane, ethyl acetate extract and methanol extract, respectively). Significant difference in the antifungal potential of the extracts $(p \leq 0.05)$ was noted in this study (Table 3). Methanol and ethyl acetate extract of leaves revealed antifungal activity against $A$. fumigatus and A. niger. The maximum inhibitory activity of ethyl acetate extracts of $V$. thapsus leaves was noted against $C$. albicans forming inhibition zones of 37, 35 and $34 \%$ at 3000, 2000 and $1000 \mu \mathrm{g} /$ well, respectively. Similarly, the minimum antifungal activity was shown by ethyl acetate extract of $V$. thapsus against $T$. rubrum by producing $4 \%$ zone of inhibition at $3000 \mu \mathrm{g} /$ well, while no activity was recorded at 2000 and $1000 \mu \mathrm{g} /$ well (Table 2). Methanol extract produced maximum inhibitory activity against $A$. solni by forming inhibition zones of 50 , 45 and $39 \%$ at 3000, 2000 and $1000 \mu \mathrm{g} /$ well, respectively, while no activity was recorded at the tested concentrations against $T$. rubrum. However, n-hexane extract was inactive against $A$. solani and $C$. albicans. T. rubrum was resistant and none of the tested extracts affect its growth.

Maximum antibacterial and antifungal potential of $V$. Thapsus leaves was noted in ethyl acetate and methanol solvent extraction system, respectively. This difference in the antibacterial or antifungal potential among the extracts might be attributed to the nature and quantity of bioactive compounds extracted in different extraction solvent system. Previously similar findings were also reported for other medicinal plants (Junaid 2006, Ghasemi et al. 2015, Qasim et al. 2017). Extraction solvent effect on the antibacterial and antifungal potency of the leaves of $V$. Thapsus was observed in this study. The findings of the research study suggest that the ethyl acetate is a suitable solvent for antibacterial activity and methanol for the antifungal activity of $V$. Thapsus. 


\section{References}

Ahvazi M., Sigaroodi FK, Charkhchiyan MM, Mojab F, Mozaffarian VA and Zakir H 2012. Introduction of Madicinal Plant species with the most traditional usage in almut region. Iran J. Pharm. Res. 11: 185-194

Cabi E, Baser B, Yavru A, Polat F, Toprak U and Karaveliogulları FA 2011. Scanning Electron Microscope (SEM) and Light Microscope (LM) studies on the seed morphology of 'Verbascum' Taxa (Scrophulariaceae) and their systematic implications. Aust. J. Crop Sci. 5: 660.

Camper ND and Turker AU 2002. Biological activity of common mullein, a medicinal plant. J. Ethnopharmacol. 82:117-125.

Dulger B, Kirmizi S, Arslan H and Güleryüz G 2002. Antimicrobial activity of three endemic Verbascum species. Pharm. Biol. 40: 587-589.

Ghasemi F, Rezaei F, Araghi A and Tabari MA 2015. Antimicrobial activity of aqueous-alcoholic extracts and the essential oil of Verbascum thapsus L. Jundishapur J. Na.t Pharm. Prod. 10:1-5.

Gilani SS and Shinwari ZK 2003. Sustainable harvest of medicinal plants at Bulashbar Nullah, Astore (Northern Pakistan). J. Ethnopharmacol. 84: 289-298.

Gurel E and Turker AU 2005. Common mullein (Verbascum thapsus L.): recent advances in research. Phytother. Res. 19: 733-739.

Hassan HS, Sule MI, Musa AM, Musa KY, Abubakar MS and Hassan AS 2012. Anti-inflammatory activity of crude saponin extracts from five Nigerian medicinal plants. Afr. J. Tradit. Complement Altern Med. 9: $250-255$.

Hassan N, Nisar M, Kakar SU, Ul F, Hassan ZZ, Nong L, Khan MI, Shuaib M and Wang D 2017. Determination of informant consensus factor of medicinal plants used as therapy in district Dir Lower Pakistan. Journal of Medicinal Plant Studies. 5: 183-8.

Hatfield G and Allen DE 2004. Medicinal plants in folk tradition, Timber Press, Cambridge, UK.

Junaid SA, Olabode AO, Onwuliri FC, Okwori AEJ and Agina SE 2006. The antimicrobial properties of Ocimum gratissimum extracts on some selected bacterial gastrointestinal isolates. Afr. J. Biotechnol. 5: 2315-2321

Kalalian-Moghaddam H, Mirzaii M, Khaksari M, Fazli M, Rahimi F and Behzadi AA 2015. Antibacterial and anti-adherent activity of great mullein (Verbascum thapsus L.) ethanolic extract on in vitro biofilm formation of three oral streptococci. IJHS 1:34-37.

Khan AM, Qureshi RA, Gillani SA and Faizan U 2011. Antimicrobial activity of selected medicinal plants of Margalla Hills, Islamabad, Pakistan. J. Med. Plants Res. 5: 4665-4670.

Khan W, Bakht J and Khan BM 2017. In vitro antifungal, anti-oxidant and HPLC analysis of the extracts of Physalis philadelphica. Bangl. J. Pharmacol. 12: 313-318.

Khan W, Bakht J and Shafi M 2016. Evaluation of polyphenol content in different parts of Physalis ixocarpa. Pak J Bot. 48: 1145-1151.

Khan W, Jehan B and Mohammad S 2016. Antimicrobial potentials of different solvent extracted samples from Physalis ixocarpa. Pak. J. Pharm. Sci. 29: 467-475.

Khan W, Jehan B, Nair MG, Uddin MN and Mohammad S 2018. Extraction and isolation of important bioactive compounds from the fruit of Physalis ixocarpa. Pak. J. Pharm. Sci. 31: 2463-2469.

Murad W, Ahmad A, Gilani SA and Khan MA 2011. Indigenous knowledge and folk use of medicinal plants by the tribal communities of Hazar Nao forest, Malakand District, North Pakistan. J. Med. Plants Res. 5: 1072-1086.

Ngo TV, Scarlett CJ, Bowyer MC, Ngo PD and Vuong QV 2017. Impact of different extraction solvents on bioactive compounds and antioxidant capacity from the root of Salacia chinensis L. Journal of Food Quality: 1-8. https://doi.org/10.1155/2017/9305047.

Onivogui G, Letsididi R, Diaby M, Wang L and Song Y 2016. Influence of extraction solvents on antioxidant and antimicrobial activities of the pulp and seed of Anisophyllea laurina $\mathrm{R}$. Br. ex Sabine fruits. Asian Pac. J. Trop. Biomed. 6: 20-25.

Prakash V, Rana S and Sagar A 2016. Studies on antibacterial activity of Verbascum thapsus. Journal of Medicinal Plants Studies 4: 101-103. 
Qasim M, Aziz I, Rasheed M, Gul B and Khan MA 2016. Effect of extraction solvents on polyphenols and antioxidant activity of medicinal halophytes. Pak. J. Bot. 48: 621-7.

Qureshi RA, Ahmed M and Ghufran MA 2007. Indigenous knowledge of some important wild plants as folk medicines in the area of Chhachh (distt. Attock) Punjab, Pakistan. Electron. J. Environ. Agr. Food Chem. 6: 2500-2511.

Rajbhandari M, Mentel R, JHA PK, Chaudhary RP, Bhattarai S, Gewali MB, Karmacharya N, Hipper M and Lindequist U 2009. Antiviral activity of some plants used in Nepalese traditional medicine. EvidBased.Compl. Alt. 6: 517-522.

Riaz M, Haq MZU and Jaafar HZE 2013. Common mullein pharmacological and chemical aspects. Rev. Bras. Farmacogn. 23: 948-959.

Sher H 2011. Ethno ecological evaluation of some medicinal and aromatic plants of Kot Malakand Agency. Pakistan. Sci. Res. Essays. 6: 2164-2173.

(Manuscript received on 5 February, 2019; revised on 4 August, 2020) 